\title{
FOLLOW THE EVENTS IN THE INDONESIAN LANGUAGE EXPRESSIVE SAID TRANSACTION IN THE TRADITIONAL MARKET TOWN OF BAUBAU
}

\author{
${ }^{1}$ Harziko, ${ }^{2}$ Ikhwan M. Said, ${ }^{3}$ Kamsinah \\ ${ }^{123}$ Program Studi Bahasa Indonesia, Fakultas Ilmu Budaya, \\ Universitas Hasanuddin, Makassar \\ harziko91@gmail.com \\ ionesaid@gmail.com \\ kamsinah@unhas.ac.id
}

\begin{abstract}
Expressive speech acts are often used in both environments, schools, offices, hospitals and market. This research aims to describe the function of speech is expressive of sellers and buyers in the event of transaction in the traditional market town of Baubau. This qualitative descriptive nature of the research. Sampling is done in purposif. Linguistic phenomena is examined with a pragmatic approach. Research data in the form of verbal data sourced from the conversation of sellers and buyers in a transaction. The data was collected by using the method of observation through the technique of record and note. The data have been analyzed in qualitative descriptive are classified. The results showed that the functions of the seller's expressive speech consists of functions to thank, praise, and function function complained. Furthermore the functions of speech is expressive of the buyer, i.e. the function to thank, praise, function and the function of complaining.

Keywords: mode, the seller and the buyer, the conversation.
\end{abstract}

\section{PENDAHULUAN}

Tuturan ekspresif adalah jenis tindak tutur yang merupakan cerminan perasaan penutur. Tindak tutur ini diekspresikan dengan berbagai macam ekspresi yang diwujudkan dengan tindakan atau tuturan berupa kegembiraan, kesulitan, kesukaan, kebencian, kesenangan, atau kesengsaraan. Hal tersebut sejalan dengan pendapat Wijana (1996) yang mengatakan tuturan ekspresif digunakan untuk menyatakan sikap psikologis pembicara terhadap sesuatu keadaan.

Tindak tutur ekspresif sering digunakan pada lingkungan sekolah, kantor, rumah sakit dan di pasar. Pasra (2014) pasar tradisional diartikan sebagai wadah atau tempat sekaligus wahana jual-beli barang berbagai kebutuhan hidup sehari-hari seperti sembako, pakaian, sepatu dan sendal, sayur- mayur, dan buah. Istilah pasar diartikan sebagai tempat berkumpulnya sejumlah penjual dan pembeli dimana terjadi transaksi jual-beli barang-barang yang ada di sana.

Pasar merupakan salah satu tempat bertemunya penjual dan pembeli dalam melakukan interaksi jual-beli. Interaksi penjual dan pembeli dibangun melalui percakapan dalam proses tawar-menawar. Dalam interaksi sosial yang dibangun melalui tawar-menawar, pembeli diposisikan layaknya raja dan penjual menempatkan dirinya sebagai pelayan untuk meningkatkan pelayanan yang memuaskan pembeli. Hal tersebut akan tercapai apabila penjual mempunyai keterampilan menawarkan barang yang dijual. Selain itu, penjual harus pula menyesuaikan tuturannya dengan kebutuhan pembeli. Demikian halnya dengan pembeli, salah satu keterampilan 


\section{4 | JURNAL ILMU BUDAYA}

Volume 6, Nomor 1, Juni 2018

pembeli adalah menawar harga barang yang dipilihnya. Pada proses tersebut, penjual dan pembeli akan menghasilkan keberagaman tuturan dengan harapan setiap maksud tuturannya dapat dipahami.

Tarigan (1990) menyatakan bahwa berkaitan dengan tindak tutur maka setiap ujaran atau ucapan tertentu akan mengandung maksud dan tujuan tertentu pula. Dengan kata lain, penutur dan mitra tutur yang terlibat dalam peristiwa tutur akan menghasilkan tuturan yang berorientasi pada maksud tertentu. Pada peristiwa tutur, penjual dan pembeli dapat berinteraksi melalui proses tawar-menawar. Dalam proses tawar-menawar akan berlangsung dengan baik apabila terjadinya kebersamaan dan kesepahaman pada maksud tuturan yang diujarkan.

Untuk menyampaikan maksud tertentu, penutur sering juga menggunakan modus kalimat yang disampaikan secara tidak langsung. Tujuannya untuk meminimalisasi kesalahpahaman antara penjual dan pembeli. Oleh sebab itu, melalui analisis percakapan dapat diketahui makna tersembunyi yang disampaikan oleh penjual dan pembeli berdasarkan konteks tuturan. Sebagaimana yang dikatakan oleh Burhan (2007) bahwa analisis percakapan berfokus pada pesan yang tersembunyi (laten) dengan cara melakukan interpretasi terhadap teks, membaca simbol-simbol, dan memahami makna interaksi simbolik yang terjadi dalam komunikasi.

Penelitian ini merupakan salah satu penelitian dengan dasar tinjauan pragmatik. Tinjauan pragmatik dapat digunakan untuk mengungkap berbagai macam bentuk tuturan, makna, maksud, dan aspek-aspek situasi tutur dalam percakapan. Zamzani (2007) berpendapat kajian pragmatik selalu terarah pada permasalahan bahasa dalam suatu masyarakat.

Menurut Soeparno (2002) pragmatik adalah subdisiplin linguistik yang
E-ISSN: 2621-5101 P-ISSN:2354-7294

mempelajari penerapan atau penggunaan bahasa dalam komunikasi sosial harus memperhatikan faktor-faktor situasi, maksud pembicaraan, dan status lawan tutur. Gusnawati (2011) mengatakan bahwa pragmatik berfokus utama pada dua kata kunci, yakni penggunaan bahasa dalam konteksnya, dan makna yang ditimbulkan akibat interaksi sosial yang bergantung pada hubungan solidaritas atau jarak antara interlokutor.

Tindak tutur dalam pragmatik merupakan salah satu konsep dalam kebahasaan. Menurut Rohmadi, (2004) tindak tutur merupakan gejala individual yang bersifat psikologis dan keberlangsungan ditentukan oleh kemampuan bahasa penutur dalam menghadapi situasi tertentu. Salah satu jenis tindak tutur yang sering ditemukan pada setiap percapakan adalah tindak ekspresif. Menurut Rani, dkk. (2006) tindak tutur ekspresif adalah tindak tutur yang menyangkut perasaan dan sikap. Tindak tutur ekspresif diungkapkan berdasarkan pernyataan psikologis dapat berupa pernyataan kegembiraan, kesulitan, kebencian, kesenangan, dan kekecewaan. Tindak tutur ekspresif mengimplikasikan bahwa penutur mempunyai fungsi untuk mengekspresikan, mengungkapkan atau memberitahukan sikap psikologis sang pembicara menuju suatu pernyataan keadaan yang diperkirakan oleh ilokusi. Misalnya mengucapkan terima kasih, mengucapkan selamat, memuji, humor, mengajak, menolak, basa-basi dan sebagainya.

Berkaitan dengan hal di ataas, peneliti tertarik untuk meneliti percakapan penjual dan pembeli yang dilatarbelakangi oleh beberapa hal, antara lain a) beragamnya penggunaan modus tuturan yang kadangkadang tidak sesuai dengan fungsi sebenarnya, b) percakapan penjual dan pembeli hanya sekadar dipandang sebagai salah satu titik dari rangkaian alur proses percakapan untuk memenuhi keinginannya. 


\section{5 | JURNAL ILMU BUDAYA}

Volume 6, Nomor 1, Juni 2018

Oleh karena itu penelitian ini bertujuan untuk mendeskripsikan fungsi tuturan ekspresif penjual dan pembeli dalam peristiwa transaksi jual-beli di pasar tradisional Kota Baubau.

\section{METODE PENELITIAN}

\section{Jenis Penelitian dan Pendekatan}

Penelitian ini merupakan jenis penelitian deskriptif kualitatif dengan menggunakan pendekatan pragmatik. Penelitian deskriptif kualitatif adalah penelitian yang mengidentifikasi, mengklasifikasi, menganalisis data yang telah diperoleh, dan pendeskripsiannya berupa penggambaran bahasa sebagaimana adanya (Sudaryanto, 1993). Dengan demikian, pendeskripsian data dalam penelitian ini berupa tuturan pedagang dan pembeli di pasar tradisional Kota Baubau dari segi modus dan fungsi tindak tutur ekspresif dalam transaksi jualbeli mereka dengan menggunakan konsepkonsep teori yang telah dikembangkan oleh para ahli pragmatik. Pendekatan pragmatik digunakan untuk menjelaskan penggunaan tindak tutur penjual dan pembeli yang ditinjau dari segi modus dan fungsi tindak tutur ekspresif mereka berdasarkan konteks.

\section{Sumber dan Jenis Data}

Sumber data penelitian ini, yaitu tuturan penjual dan pembeli di pasar tradisional Kota Baubau. Sementara, jenis datanya adalah data lisan berupa tuturan ekspresif yang digunakan penjual dan pembeli di pasar tradisional Kota Baubau. Menurut Subroto (2007) sumber data adalah asal data yang diperoleh dan data sebagai obyek penelitian umum adalah semua informasi atau bahan yang disediakan oleh alam (dalam arti luas) yang harus dicari atau dikumpulkan dan dipilih oleh peneliti

\section{Lokasi dan Waktu Penelitian}

Waktu pelaksanaan penelitian akan dilakukan selama satu bulan. Penelitian ini berlokasi di pasar tradisional Kota Baubau. Lokasi tersebut dipilih karena pasar tradisional merupakan salah satu pusat

\section{E-ISSN: 2621-5101 P-ISSN:2354-7294}

pertemuan antara kelompok sosial masyarakat dari berbagai daerah yang memiliki ragam tuturan yang berbeda-beda berdasarkan pengalaman individu masingmasing saat menyapa, bertanya, menawar, mempersilahkan, membujuk, dan lain-lain. Hal ini sebagai cerminan tuturan dalam proses tawar-menawar antara penjual dan pembeli.

\section{Metode dan Teknik Pengumpulan Data}

Metode yang digunakan adalah metode simak dengan mengumpulkan data langsung dari lapangan dengan cara merekam tindak tutur yang digunakan penjual dan pembeli dalam transaksi jual-beli yang berlangsung di pasar tradisional Kota Baubau. Mahsun, (2007) metode simak adalah metode yang digunakan untuk memperoleh data dengan menyimak penggunaan bahasa. Metode ini digunakan untuk mendapatkan data lisan, yaitu data berupa tuturan penjual di pasar tradisional Kota Baubau. Teknik yang digunakan dalam penelitian ini adalah teknik rekam dan catat. Perekaman data menggunakan alat perekam handphone untuk merekam percakapan pedagang dan pembeli di saat proses tawar-menawar berlangsung. Teknik rekam digunakan dengan pertimbangan bahwa data yang diteliti berupa tuturan lisan yang digunakan penjual dan pembeli di pasar tradisional Kota Baubau. Dalam teknik catat yaitu penulis mencatat data-data yang ada hubungannya dengan masalah. Proses catat ini merupakan tindak lanjut dari teknik rekaman tindak tutur ekspresif yang digunakan penjual dan pembeli di pasar tradisional Kota Baubau.

\section{Teknik Analisis Data}

Analisis data merupakan tahap setelah data terkumpul. Dalam menganalisis data. Penulis menggunakan analisis pragmatik, yaitu analisis bahasa berdasarkan sudut pandang pragmatik (Rustono, 1999). Proses analisis data dimulai dengan menelaah seluruh data yang tersedia dari berbagai 


\section{6 | JURNAL ILMU BUDAYA}

Volume 6, Nomor 1, Juni 2018

sumber kemudian dijelaskan secara sistematis untuk memberikan gambaran secara cermat mengenai permasalahan yang dibahas sesuai dengan rumusan masalah dan tujuan penelitian.

Menurut sudaryanto (1993) analisis data adalah upaya peneliti menangani langsung masalah yang terkandung dalam data. Penerapan langkah-langkah tersebut dapat diuraikan sebagai berikut. Proses analisis data dilakukan melalui tahap identifikasi data, yakni mengidentifikasi rekaman tuturan pedagang dan pembeli yang telah dicatat, kemudian memilih bentuk tuturan yang mengandung modus dan fungsi tindak tutur ekspresif mereka. Selanjutnya melakukan klasifikasi pada data yang telah dikumpulkan, yakni tuturan yang mengandung modus dan fungsi tindak tutur ekspresif. Dalam penelitian ini klasifikasi dilakukan dengan mengurutkan data sesuai dengan tujuan penelitian yang ingin dicapai. Data yang telah diklasifikasi selanjutnya dianalisis berdasarkan teori yang berkaitan dengan modus dan tindak tutur ekspresif. Guna mencapai analisis yang sesuai dengan rumusan masalah, maka data yang diperoleh dari hasil rekaman tuturan penjual dan pembeli akan dicatat lalu dianalisis. Langkah terakhir adalah menyimpulkan hasil penelitian berdasarkan data yang telah dideskripsikan, diidentifikasi, diklasifikasi, dan dianalisis.

\section{HASIL PENELITIAN}

Pada penelitian ini ditemukan tiga fungsi tuturan ekspresif penjual yang dipengaruhi oleh berbagai konteks, yaitu (1) mengucapkan terima kasih dengan menggunakan penanda satuan lingual terima kasih, (2) fungsi tuturan ekspresif memuji dengan menggunakan penanda satuan lingual segar, manis, dan bagus, dan (3) fungsi tuturan ekspresif mengeluh dengan menggunakan penanda satuan lingual susah, adoh, dan juga. Selanjutnya, ditemukan tiga
E-ISSN: 2621-5101 P-ISSN:2354-7294

fungsi tuturan ekspresif pembeli yang dipengaruhi oleh berbagai konteks, yaitu (1) fungsi mengucapkan terima kasih dengan menggunakan penanda satuan lingual terima kasih, (2) fungsi tuturan ekspresif memuji dengan menggunakan penanda satuan lingual bagus-bagus, lebih cantik, murahnya di sini, dan (3) fungsi tuturan ekspresif mengeluh dengan menggunakan penanda satuan lingual tipis, jarang, mahal.

\section{PEMBAHASAN}

Berikut akan dipaparkan hasil penelitian berkaitan dengan Tindak Tutur Ekspresif Bahasa Indonesia dalam Peristiwa Transaksi Jual-Beli di Pasar Tradisional Kota Baubau sesuai dengan rumusan masalah dan tujuan penelitian. Dalam hal ini berkaitan dengan penggunaan fungsi tuturan ekspresif penjual dan pembeli dalam peristiwa transaksi jualbeli.

Contoh (1)

Konteks : Seorang penjual menjual terung.

Tempat : Pasar Wameo Kota Baubau

Peserta: Penjual dan pembeli

Percakapan :

Penjual : Tidak beli terung

langganan?

Pembeli : Berapa itu?

Penjual : Sepuluh ribu.

Pembeli : Mahalnya.

Penjual : Besar-besar itu.

Pembeli : Ambilkan mi yang di ujung

itu.

Penjual : Terima kasih di.

Pembeli : Makasih kembali. Jalan

dulu.

Melalui contoh (1) terdapat tindak tutur ekspresif yang dituturkan penjual. Piranti linguistik yang menjadi penandanya adalah frasa terima kasih di. Frasa terima kasih mempunyai fungsi mengucapkan rasa syukur. Pada konteks ini, fungsi mengucapkan terima kasih disampaikan 
107 | JURNAL ILMU BUDAYA

Volume 6, Nomor 1, Juni 2018

penjual sebagai ungkapan rasa senangnya karena pembeli telah membeli terung. Hal tersebut disampaikan setelah terjadi kesepakatan harga oleh mereka. Selain itu, fungsi mengucapkan terima kasih disampaikan setelah pembeli membayar harga terung dan menerima terung yang dibayarnya dari penjual.

Contoh (2)

Konteks : Seorang penjual menjual nenas

Tempat : Pasar Wameo Kota Baubau.

Peserta : Penjual dan pembeli.

\section{Percakapan :}

Penjual :Apa itu?

Penjual : Ada yang sepuluh, ada yang

lima belas, ada yang dua puluh.

Pembeli : Manis ini?

Penjual : Manis itu. Sudah dirasa itu sebelum saya jual.

Pembeli : Nenas dari mana ini?

Penjual : Dari Raha.

Pembeli :Berapa ini?

Penjual : Lima belas.

Pembeli : Ih sepuluh mi.

Penjual : Kita juga ambil lima belas. Saya kasih pelaris saja itu

Merujuk pada contoh (2) terdapat tindak tutur ekspresif memuji yang dituturkan penjual. Piranti linguistik yang menjadi penandanya adalah frasa manis itu. Manis berarti menyiratkan sesuatu yang rasanya seperti gula, dan kata itu merupakan kata penunjuk yang menyiratkan keberadaan nenas. Merujuk pada konteks di atas, frasa manis itu berfungsi memuji. Dalam hal ini, penjual memuji nenas yang dijualnya dengan tujuan meyakinkan pembeli. Penjual menyampaikan pujiannya karena pembeli memberikan pertanyaan. Hal ini ditemukan pada kalimat manis ini. Kalimat tersebut mengindikasikan bahwa pembeli kurang yakin kalau nenas penjual memiliki rasa yang manis. Dengan demikian, penjual
E-ISSN: 2621-5101 P-ISSN:2354-7294

memuji nenas yang dijualnya agar pembeli yakin dan membeli nenas.

Contoh (3)

Konteks : Seorang penjual menjual ikan

Tempat : Pasar Wameo Kota Baubau.

Peserta: Penjual dan pembeli.

Percakapan :

Penjual : Yang mana Bu?

Pembeli : Berapa satu tempat ikan

lure?

Penjual : Dua puluh. Murah ini Bu.

Pembeli : Kecil-kecilnya juga dan.

Sepuluh mi eee.

Penjual : Adoh biar nasi kuning kita tidak bisa beli lagi itu.

Merujuk pada contoh (3) ditemukan adanya tindak tutur ekspresif mengeluh yang dituturkan penjual. Piranti linguistik yang menjadi penandanya ditemukan pada kalimat adoh biar nasi kuning kita tidak bisa beli lagi itu yang berfungsi mengeluh. Kata adoh bentuk bakunya adalah aduh merupakan kata seru yang menyatakan rasa heran atau sakit. Jadi, pada konteks ini penjual menggunakan kata adoh dengan tujuan menginformasikan keluhannya bahwa dirinya tidak bisa membeli nasi kuning. Bila diperhatikan, kalimat adoh biar nasi kuning kita tidak bisa beli lagi itu tidak berkaitan dengan proses tawar-menawar ikan antara penjual dan pembeli. Namun, pada situasi ini, kalimat adoh biar nasi kuning kita tidak bisa beli lagi itu digunakan penjual karena pembeli menawar terlalu rendah dari harga ikan lure yang ditetapkan dirinya. Jadi, penjual merasa tidak dapat membeli nasi kuning bila mengikuti tawaran pembeli.

Contoh (4)

Konteks : Seorang pembeli membeli gula 
108 | JURNAL ILMU BUDAYA

Volume 6, Nomor 1, Juni 2018

Tempat : Pasar Laelangi Kota

Baubau.

Peserta : Penjual dan pembeli.

Percakapan :

Pembeli :Berapa ini?

Penjual : Delapan puluh satu ikat.

Delapan ribu satu biji.

Pembeli : Bagus ini kah. Saya mau

ambil setengah.

Penjual : Ambil saja yang ini. Itu tidak cukup.

Pembeli : Isi mi dalam kantung.

Terima kasih.

Penjual : Ia.

Pada contoh (20) terdapat TTE mengucapkan terima kasih. Piranti linguistik yang menjadi penandanya adalah frasa terima kasih di. Frasa terima kasih mempunyai fungsi mengucapkan rasa syukur. Jika pembeli tidak mendapatkan pelayanan yang baik dan kecocokan harga dengan penjual, maka pembeli tidak akan mengucapkan terima kasih. Namun, pada konteks ini frasa terima kasih disampaikan pembeli sebagai ungkapan rasa senangnya karena dia telah mendapatkan pelayanan yang baik dan kecocokan harga dari penjual. Selain itu, pembeli mengucapkan terima kasih karena dia telah membayar dan menerima gula dari penjual.

Contoh 5

Konteks : Seorang penjual menjual terung.

Tempat : Pasar Wameo Kota Baubau.

Peserta: Penjual dan pembeli.

\section{Percakapan :}

Penjual : Terung. Ini lima ribu, ini sepuluh.

Pembeli : Bagus-bagus terungnya di, Bu. Belum tua ini to.

Penjual : Masih muda, masih mengkilat itu.
E-ISSN: 2621-5101 P-ISSN:2354-7294

Pembeli : Ambilkan mi yang sepuluh.

Penjual : Tabe ini kembaliannya.

Makasih di.

Pembeli : Ie.

Pada contoh (5) terdapat tindak tutur ekspresif memuji yang dituturkan pembeli. Piranti linguistik yang menjadi penandanya ditemukan pada kalimat bagus-bagus terungnya di, Bu. Kata ulang bagus-bagus bermakna banyak yang bagus berfungsi memuji. Pada konteks ini, pembeli memuji terung sekaligus mempengaruhi penjual agar menurunkan harga terung. Jika pembeli bermaksud menawar, maka dia dapat meminta dari harga sepuluh menjadi lima ribu atau sesuai dengan harga yang diinginkan dirinya. Dengan demikian, penjual dapat mempertimbangkan tawaran pembeli. Namun, dalam situasi ini pembeli tidak menawar secara langsung sesuai harga yang diinginkannya karena dia telah menyetujui harga terung dari penjual.

\section{Contoh 6}

Konteks : Seorang pembeli mencari semangka.

Tempat : Pasar Laelangi Kota Baubau Peserta : Penjual dan pembeli

Percakapan :

Penjual : Semangkanya, Pak.

Pembeli : Berapa?

Penjual : Dua puluh ribu satu biji.

Pembeli : Manis tidak.

Penjual : Namanyajuga semangka.

Pembeli : Saya sering beli semangka tapi jarang mau dapat yang manis.

Penjual : Tergantung semangkanya, Pak.

Pembeli : : Ambilkan mi satu biji.

Penjual : Terima kasih, Pak.

Melalui contoh (4) tampak adanya tindak tutur ekspresif mengeluh yang dituturkan pembeli. Piranti linguistik yang menjadi penandanya terdapat pada kalimat saya 
E-ISSN: 2621-5101 P-ISSN:2354-7294

sering beli semangka tapi jarang mau dapat yang manis. Pada kalimat tersebut terdapat kata jarang berarti tidak mudah didapat. Berdasarkan konteksnya, kata jarang digunakan pembeli yang berfungsi mengeluh. Dalam hal ini, pembeli menyampaikan keluhannya karena dia selalu membeli dan menemukan nenas yang tidak manis. Pada konteks ini, jika pembeli pertama kali membeli nenas pada penjual, maka pembeli tidak akan menyampaikan keluhannya. Namun, kalimat saya sering beli semangka tapi jarang mau dapat yang manis mengindikasikan bahwa sebelumnya pembeli pernah membeli nenas yang kurang manis pada penjual lain. Dengan demikian, pembeli selalu menyampaikan keluhannya dalam proses tawar-menawar jika bertemu penjual nenas.

\section{SIMPULAN}

Fungsi tuturan ekspresif pedagang diantaranya mengucapkan terima kasih, memuji, dan mengeluh. Sementara, fungsi tuturan ekspresif pembeli diantaranya mengucapkan terima kasih, memuji, dan mengeluh. Ketiga fungsi tuturan penjual dan pembeli ditampakan secara nyata berdasarkan wujud tuturan yang dipakai oleh mereka. Di saat memberikan perintah atau pun penolakan sebaiknya memperhatikan konteks dengan menggunakan modus deklaratif agar orang yang diajak bicara tidak merasa diperintah. Dalam percakapan, perlu diperhatikan tutur kata yang baik agar dapat menyenangkan orang lain. Penelitian ini belum sepenuhnya mengungkap fenomena kebahasaan di pasar tradisional kota Baubau. Oleh karena itu, bagi peneliti lain yang tertarik untuk meneliti hal yang berkaitan dengan penelitian ini, dapat mengkaji dari sudut pandang yang lain, misalnya pola-pola tindak tutur yang dikaitkan dengan aspek usia.

\section{DAFTAR PUSTAKA}

Burhan, Bungin. 2007. Penelitian Kualitatif. Jakarta: Kencana.

Gusnawaty. 2011. "Perilaku Kesantunan dalam Bahasa Bugis:Analisis Sosiopragmatik". Disertasi. Makassar. Pascasarjana Universitas Hasanuddin.

Mahsun. M.S. 2007. Metode Penelitian Bahasa. Jakarta: Raja Gravindo Persada.

Pasra, Mubbasirang. 2014. "Studi Perilaku Perjalanan Berbelanja ke Pasar Tradisional di Wilayah Perkotaan". Disertasi. Makassar. Pascasarjana Universitas Hasanuddin.

Rani, Abdul, dkk. 2006. Analisis Wacana: Sebuah Kajian Bahasa dalam Pemakaian. Malang: Bayu Media Publishing.

Rohmadi, Muhammad. 2004. Pragmatik: Teori dan Analisis. Yogyakarta: Lingkar Media.

Rustono. 1999. Pokok-Pokok Pragmatik. Semarang: CV. IKIP Semarang Press.

Soeparno. 2002. Dasar-Dasar Linguistik Umum. Yogyakarta: Tiara Wacana.

Subroto, Edi 2007. Pengantar Metode Penelitian Linguistik Struktural. Surakarta: Universitas Sebelas Maret Press.

Sudaryanto. 1993. Metode dan Aneka Teknik Analisis Bahasa. Yogyakarta: Duta Wacana University Press.

Tarigan, Henry Guntur. 1990. Teknik Pengajaran Keterampilan Berbahasa. Bandung: Angkasa.

Wijana, Dewa Putu. 1996. Dasar-Dasar Pragmatik. Yogyakarta: Andi Offset.

Zamzani. 2007. Kajian Sosiopragmatik. Yogyakarta: Cipta Pustaka. 